\title{
Cytotoxic Effects of Verbascoside on MCF-7 and MDA-MB-231
}

\section{Verbaskositin MCF-7 ve MDA-MB-231 Üzerindeki Sitotoksik Etkileri}

\author{
(D) Hülya ŞENOL ${ }^{1 *}$, (D) Pınar TULAY2,3, (D) Mahmut Çerkez ERGÖREN2,3, (D) Azmi HANOĞLU4 ${ }^{4}$ (D) İhsan ÇALIȘ4, (D) Gamze MOCAN5 \\ ${ }^{1}$ Near East University Faculty of Medicine, Department of Medical Biology, Nicosia, North Cyprus \\ 2Near East University Faculty of Medicine, Department of Medical Genetics, Nicosia, North Cyprus \\ ${ }^{3}$ Near East University, Desam Research Institute, Nicosia, Cyprus \\ 4Near East University Faculty of Pharmacy, Department of Pharmacognosy, Nicosia, North Cyprus \\ 5 Near East University Faculty of Medicine, Department of Medical Pathology, Nicosia, North Cyprus
}

\begin{abstract}
Objectives: Verbascoside, also known as acteoside/kusaginin, has attracted a great attention due to its pharmacological features. In this study, we aimed to determine the cytotoxic effects of pure verbascoside isolated from Phlomis nissolii L. plant in both MCF-7 and MDA-MB-231 cell lines in vitro.

Materials and Methods: MCF-7 and MDA-MB 231 cells were treated with verbascoside $(100,48,25,10,1,0.5$, and $0.1 \mu \mathrm{M})$ for 24,48 , and 72 hours. Cytotoxic effect of verbascoside in MCF-7 and MDA-MB-231 cells was assessed using TEBU-BIO cell counting kit 8.

Results and Conclusion: $\mathrm{IC}_{50}$ values for 24,48 , and $72 \mathrm{~h}$ verbascoside exposure of MCF-7 cells were determined as $0.127,0.2174$, and $0.2828 \mu \mathrm{M}$, respectively. $R^{2}$ values were calculated as $0.9630,0.8789$ and 0.8752 , respectively. Two-Way ANOVA multiple comparison test results showed that $100 \mu \mathrm{M}$ verbascoside has the highest cytotoxic effect on MCF-7 breast cancer (BC) cells after $72 \mathrm{~h}$ of exposure. IC $\mathrm{C}_{50}$ values for 24,48 and 72 h verbascoside exposure of MDA-MB 231 cells were determined as $0.1597,0.2584$ and $0.2563 \mu \mathrm{M}$, respectively and $R^{2}$ values were calculated as $0.8438,0.5107$ and 0.9203 , respectively. Two-Way ANOVA multiple comparisons test results showed that $100 \mu \mathrm{M}$ verbascoside has the highest cytotoxic effect on MDA-MB $231 \mathrm{BC}$ cells after 24, 48 and $72 \mathrm{~h}$ of exposure.
\end{abstract}

Key words: Cytotoxicity, MCF-7, MDA-MB-231, Phlomis nissolii L., verbascoside

\section{ÖZ}

Amaç: Akteosit/kusaginin olarak bilinen verbaskosit, farmakolojik özelliklerinden dolayı büyük ilgi görmüștür. Bu çalışmada, Phlomis nissolii L. bitkisinden izole edilen saf verbaskositin MCF-7 ve MDA-MB-231 hücre hatlarında in vitro koşullarda sitotoksik etkilerini belirlemeyi amaçladık.

Gereç ve Yöntemler: MCF-7 ve MDA-MB 231 hücreleri, 24, 48 ve 72 saat süreyle 100, 48, 25, 10, 1, 0,5 ve 0,1 $\mu$ M verbaskosit ile muamele edildi. Verbaskositin MCF-7 ve MDA-MB-231 hücrelerinde sitotoksisite etkisi TEBU-BIO hücre sayım kiti 8 kullanılarak değerlendirildi.

Bulgular ve Sonuç: MCF-7 hücrelerinin 24, 48 ve 72 saatlik verbaskosit maruziyetine ilișkin IC ${ }_{50}$ değerleri sırasıyla $0,127,0,2174$ ve $0,2828 \mu \mathrm{M}$ olarak belirlendi. $R^{2}$ değerleri sırasıyla $0,9630,0,8789$ ve 0,8752 olarak hesaplanmıștır. İki yönlü ANOVA çoklu karșılaștırma testi sonuçları, $100 \mu \mathrm{M}$ verbaskositin 72 saatlik maruziyetinin MCF-7 meme kanseri (BC) hücrelerinde en yüksek sitotoksik etkiye sahip olduğunu gösterdi. MDA-MB 231 hücrelerinin 24, 48 ve 72 saatlik verbaskosite maruziyeti için $\mathrm{IC}_{50}$ değerleri sırasıyla 0,1597, 0,2584 ve 0,2563 $\mu \mathrm{M}$ olarak belirlendi. $\mathrm{R}^{2}$ değerleri sırasıyla 0,8438, 0,5107 ve 0,9203 olarak hesaplandı. İki yönlü ANOVA çoklu karşılaștırma test sonuçları, $100 \mu \mathrm{M}$ verbaskositin 24,48 ve 72 saatlik maruziyettinin MDA-MB 231 BC hücrelerinde en yüksek sitotoksik etkiye sahip olduğunu gösterdi.

Anahtar kelimeler: MCF-7, MDA-MB-231, Phlomis nissolii L., verbaskosit 


\section{INTRODUCTION}

Breast cancer $(\mathrm{BC})$ is the most frequent cancer type found among women, affecting 2.1 million women each year.' In 2018, the female deaths due to $\mathrm{BC}$ was 627 , which compromises $15 \%$ of all cancer deaths among women. Furthermore, BC rates in women are higher in more developed regions than in developing countries, and threateningly, these rates are still increasing in every region globally. According to statistical data obtained by the Ministry of Health in North Cyprus, a total of 1.854 men and 1.809 women were diagnosed with cancer between 2012 and 2016. BC has the highest incidence (62.2\%) among women in North Cyprus, and this value is lower than the incidence in Europe but unfortunately, however, higher than the $\mathrm{BC}$ incidence globally. ${ }^{2}$ The current treatment strategies for $\mathrm{BC}$ include radiotherapy + adjuvant chemotherapy, radiation therapy, hormone therapy, and surgery have side effects. ${ }^{3}$ These may include rib fracture, second non-breast infield malignancies, tissue necrosis, brachial plexopathy in radiation therapy, reduced number of white and red blood cells, elevated risk of infection, anemia, diarrhea, fatigue, hair loss, sore throat, ulcers, nausea, constipation, loss of appetite, and change in skin color during chemotherapy. ${ }^{3}$ Due to these side effects, there has been a growing interest in alternative treatment modalities with reduced side effects. ${ }^{4}$ There are many studies that have identified anti-cancer properties of herbal medicines that are used in developing countries for medical treatment for many years. ${ }^{5}$

Verbascoside $\left(\mathrm{C}_{29} \mathrm{H}_{36} \mathrm{O}_{15}\right)$, known as acteoside/kusaginin, is a phenylethanoid glycoside. Verbascoside has been isolated from many different plant species such as: Verbascum sinuatum L., ${ }^{6}$ Syringa vulgaris, ${ }^{7}$ Orobancherapum-genistae, ${ }^{8}$ Clerodendron trichotomum Thunb, ${ }^{9}$ Phlomis nissolii L. (Lamiaceae), ${ }^{10}$ Buddleja brasiliensis, Striga asiatica, Olea europea, Paulownia tomentosa var. tomentosa, Lippia javanica, Lantana camara, and Lippia citriodora." In addition, verbascoside is abundant in olive mill wastewater..$^{12,13}$ There are total of 34 genus Phlomis species $L$. found in Turkey and Aegean islands. ${ }^{14}$ The project performed on the 33 Phlomis species recorded in the Flora of Turkey resulted in the isolation and characterization of 33 phenylethanoid glycosides, of which verbascoside and forsythoside B were the common compounds for all of the Phlomis species.15 Recently, two compounds were isolated from the two endemic Phlomis species, P. brevibracteata, and P. cypria growing in Cyprus. ${ }^{16}$ Verbascoside attracted great attention due to its pharmacological features, ${ }^{17}$ such as anti-inflammatory effect, ${ }^{18-24}$ antioxidative effect, ${ }^{25-32}$ neuroprotective effect, $33-43$ antimicrobial effect ${ }^{44-46}$ ultraviolet radiation protective effect ${ }^{47-51}$ antimetastatic effect, ${ }^{52}$ and cytotoxic effects on many types of cancer such as myeloma and leukemia ${ }^{53-56}$ human gastric carcinoma, ${ }^{57}$ colorectal cancer, ${ }^{58}$ human oral squamous cell carcinoma, ${ }^{59}$ glioblastoma, ${ }^{60}$ and inhibitory effect on tumor cell proliferation. ${ }^{61}$ In this study, we aimed to determine the cytotoxic effects of pure verbascoside isolated from the Phlomis nissolii L. plant in both MCF-7 and MDA-MB-231 cell lines in vitro.

\section{MATERIALS AND METHODS}

\section{Cell culture conditions}

The compound verbascoside used in this study was provided from the studies performed on Phlomis species L. Çalış et al. ${ }^{15}$ Human BC cells MCF-7 and MDA-MB-231 (ATCC) were cultured in DMEM/F-12 media supplemented with $10 \%$ fetal bovine serum, human insulin of $4 \mathrm{mg} / \mathrm{mL}$, penicillin streptomycin $(1 \%)$ at $37^{\circ} \mathrm{C}$, in a $5 \% \mathrm{CO}_{2}$ containing humidified chamber. The medium was refreshed every other day.

\section{Cell viability/cytotoxicity}

MCF-7 and MDA-MB 231 BC cells were plated in 96-well plates in triplicate with a density of 5000 cells/well. The cells were treated with verbascoside after $24 \mathrm{~h}$ of culturing at a different concentrations $(100,48,25,10,1,0.5$, and $0.1 \mu \mathrm{M})$ for 24,48 , and 72 h. CCK-8 (Tebu, France) analysis was performed according to the manufacturer's protocol. The absorbencies were measured using Versa max tunable microplate reader at $450 \mathrm{~nm}$ wavelength.

\section{Statistical analysis}

GraphPad ${ }^{\circledR}$ Prism software version 8 was used to calculate $\mathrm{IC}_{50}$ values by applying a non-linear regression curve fit analysis. Further, statistical analysis was performed using Two-Way ANOVA multiple comparisons test to determine the significance of a mean difference between the control and varying concentrations of verbascoside.

\section{RESULTS}

\section{Cytotoxic effects of verbascoside in MCF-7 cells}

To assess the cytotoxicity of verbascoside, MCF- 7 BC cells were treated with several concentrations of verbascoside (100, $48,25,10,1,0.5$, and $0.1 \mu \mathrm{M}$ ) for 24,48 , and $72 \mathrm{~h}$. IC $\mathrm{C}_{50}$ values of verbascoside in MCF-7 cells are shown in Table 1.

Significance ofamean difference between control and other concentrations of verbascoside for MCF-7 cell line after 24 , 48, and $72 \mathrm{~h}$ was determined using Two-Way ANOVA multiple comparisons test, and the results are shown in Figure 1-3, respectively.

Two-Way ANOVA multiple comparisons test results for MCF7 cell line after $24 \mathrm{~h}$ exposure to different concentrations of verbascoside showed tha the, mean difference wasnot significant at the $95 \%$ confidence level $(\mathrm{Cl})$ between the control and the test group at 48, 25, and $10 \mu \mathrm{M}$ verbascoside concentrations. However, significance (at $p<0.05$ ) was observed at $100,1,0.5$, and $0.1 \mu \mathrm{M}$ verbascoside concentrations, and the control group after $24 \mathrm{~h}$ exposure. When concentration of verbascoside was decreased from 100-10 $\mu \mathrm{M}$, absorbency

Table 1. $I C_{50}$ and $R^{2}$ values for MCF-7 cell line

\begin{tabular}{lll} 
Exposure time to verbascoside & $\mathrm{IC}_{50}(\mu \mathrm{M})$ & $\mathrm{R}^{2}$ \\
\hline $24 \mathrm{~h}$ & 0.127 & 0.9630 \\
\hline $48 \mathrm{~h}$ & 0.2174 & 0.8789 \\
\hline $72 \mathrm{~h}$ & 0.2828 & 0.8752 \\
\hline
\end{tabular}




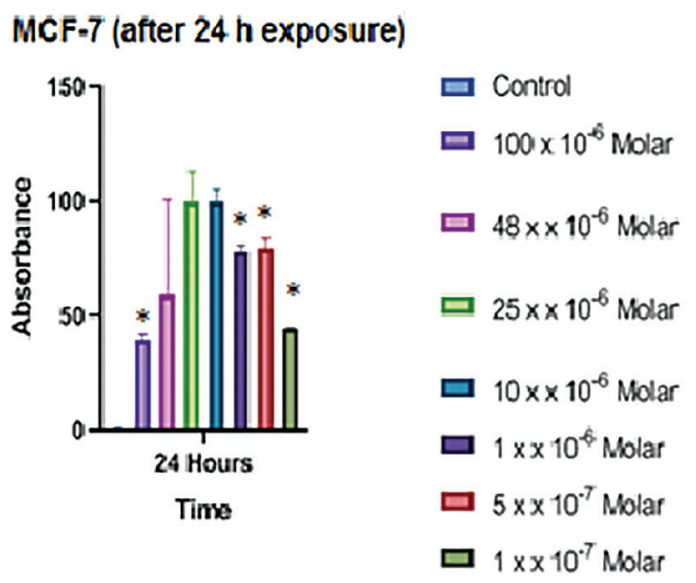

Figure 1. Two-Way ANOVA multiple comparisons test results for MCF-7 cell line after $24 \mathrm{~h}$ exposure to a different concentration of verbascoside (*significance at $p<0.05)$

\section{MCF-7 (after $48 \mathrm{~h}$ exposure)|}

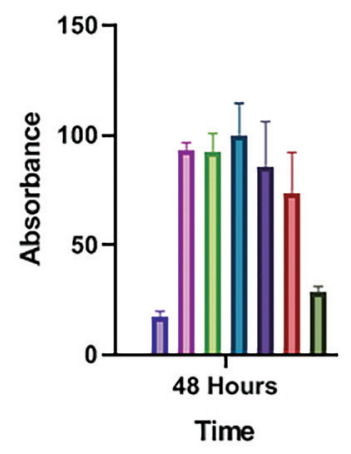

Figure 2. Two-Way ANOVA multiple comparisons test results for MCF-7 cell line after $48 \mathrm{~h}$ exposure to a different concentration of verbascoside (*significance at $p<0.05$ )

\section{MCF-7 (after $24 \mathrm{~h}$ exposure)}

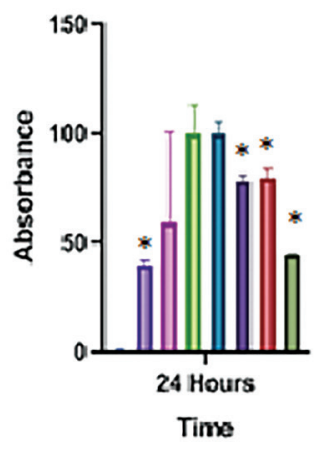

$$
\begin{aligned}
& \text { Control } \\
& \text { 口 } 100 \times 10^{-6} \text { Molar } \\
& \text { } 48 \times \times 10^{-6} \text { Molar } \\
& \text { } 25 \times \times 10^{-6} \text { Molar } \\
& \text { } 10 \times \times 10^{-6} \text { Molar } \\
& \text { } 1 \times \times 10^{-6} \text { Molar } \\
& \text { } 5 \times \times 10^{-7} \text { Molar } \\
& \text { } 1 \times \times 10^{-7} \text { Molar }
\end{aligned}
$$

Figure 3. Two-Way ANOVA multiple comparisons test results for MCF-7 cell line after $72 \mathrm{~h}$ exposure to different concentrations of verbascoside (*significance at $p<0.05$ )

increased so that the number of alive cells increased. When the concentration of verbascoside was further decreased from 10-0.1 $\mu \mathrm{M}$, absorbency decreased so that number of alive cells decreased but number of dead cells increased. All absorbency values were higher than the control group, indicating that 100 , $48,25,10,1,0.5$, and $0.1 \mu \mathrm{M}$ concentrations of verbascoside were not effectively toxic to the MCF-7 BC cells after $24 \mathrm{~h}$ exposure (Figure 1).

The mean difference was not significant at $95 \% \mathrm{Cl}$ between the control absorbency value and absorbency values obtained at $100,48,25,10,1,0.5$, and $0.1 \mu \mathrm{M}$ verbascoside concentrations after $48 \mathrm{~h}$ exposure of MCF-7 cell line. When the concentration of verbascoside was decreased from 100-10 $\mu \mathrm{M}$, absorbency increased so that the number of alive cells increased. When the concentration of verbascoside was further decreased from 10-0.1 $\mu \mathrm{M}$, absorbency decreased so that number of alive cells decreased, but the number of dead cells increased. All absorbency values were higher than the control so that 100,48 , $25,10,1,0.5$, and $0.1 \mu \mathrm{M}$ concentrations of verbascoside were not effective on MCF-7 BC cells after $48 \mathrm{~h}$ exposure (Figure 2).

The mean difference calculated by Two-Way ANOVA multiple comparisons test was not significant at the $95 \% \mathrm{Cl}$ between the control absorbency value and absorbency values obtained at 100 , $48,25,10,1,0.5$, and $0.1 \mu \mathrm{M}$ verbascoside concentrations after $72 \mathrm{~h}$ exposure of the MCF-7 cell line. When the concentration of verbascoside decreased from 100-25 $\mu \mathrm{M}$, absorbency increased so that number of alive cells increased. When the concentration of verbascoside was further decreased from 25-0.1 $\mu \mathrm{M}$, absorbency decreased so that number of alive cells decreased but number of dead cells increased. The absorbency value at $100 \mu \mathrm{M}$ verbascoside was the lowest among the other absorbency values, so that lowest number of alive cells but highest number of dead cells was at this concentration. Verbascoside of $100 \mu \mathrm{M}$ had the highest cytotoxic effect on MCF-7 BC cells after $72 \mathrm{~h}$ exposure (Figure 3 ).

\section{Cytotoxic effects of verbascoside in MDA-MB 231 cells}

MDA-MB $231 \mathrm{BC}$ cells were treated with a several concentrations of verbascoside $(100,48,25,10,1,0.5$, and $0.1 \mu \mathrm{M})$ for 24,48 , and $72 \mathrm{~h}$ to assess the cytotoxicity of verbascoside by using TEBU-BIO cell counting kit 8 . $I C_{50}$ values of verbascoside in MDA-MB 231 cells are shown in Table 2 .

Two-Way ANOVA multiple comparisons test results for MDAMB 231BC cell line after 24,48 , and $72 \mathrm{~h}$ are shown in Figure 4-6.

Analysis of the results showed that the mean difference between the control absorbency value and absorbency values

\section{Table 2. $I C_{50}$ and $R^{2}$ values for MDA-MB 231 breast cancer cell} line

\begin{tabular}{lll} 
Exposure time to verbascoside & $\mathrm{IC}_{50}(\mu \mathrm{M})$ & $\mathrm{R}^{2}$ \\
\hline $24 \mathrm{~h}$ & 0.1597 & 0.8438 \\
\hline $48 \mathrm{~h}$ & 0.2584 & 0.5107 \\
\hline $72 \mathrm{~h}$ & 0.2563 & 0.9203 \\
\hline
\end{tabular}


obtained at $100,48,25,10,1,0.5$, and $0.1 \mu \mathrm{M}$ verbascoside concentrations was not significant at $95 \% \mathrm{Cl}$. Absorbency increased when concentration of verbascoside decreased from $100-0.5 \mu \mathrm{M}$. This result showed that the number of alive cells increased. A further decrease of concentration of verbascoside from $0.5-0.1 \mu \mathrm{M}$ caused a decrease of absorbency indicating the decreased number of number of alive cells, but the number of dead cells increased. Absorbency value at $100 \mu \mathrm{M}$ verbascoside was the lowest among the other absorbency values. This result indicated that lowest number of alive cells, but the highest number of dead cells were at this concentration. Verbascoside of $100 \mu \mathrm{M}$ had the highest cytotoxic effect on MDA-MB $231 \mathrm{BC}$ cells after $24 \mathrm{~h}$ exposure (Figure 4).

The mean difference was not significant at $95 \% \mathrm{Cl}$ between control the absorbency value and absorbency values obtained at $100,48,25,10,0.5,1$, and $0.1 \mu \mathrm{M}$ verbascoside concentrations. When concentration of verbascoside was decreased from 100$25 \mu \mathrm{M}$, absorbency increased so that the number of alive cells increased. When the concentration of verbascoside further decreased from 25-0.1 $\mu \mathrm{M}$, absorbency decreased. This result indicated that the number of alive cells decreased, but the number of dead cells increased. The absorbency value at 100 $\mu \mathrm{M}$ verbascoside was the lowest among the other absorbency values. This result showed that the lowest number of alive cells, but the highest number of dead cells, was at this concentration. Verbascoside $100 \mu \mathrm{M}$ had the highest cytotoxic effect on MDAMB 231 BC cells after 48 h exposure (Figure 5 ).

Although the calculated mean difference between the control absorbency value and absorbency values obtained at 48, 25, 10 , and $1 \mu \mathrm{M}$ verbascoside concentrations was not significant at the $95 \% \mathrm{Cl}$. The mean difference was significant at $95 \%$ $\mathrm{Cl}$ (*significance at $\mathrm{p}<0.05$ ) between the control absorbency value and absorbency values obtained at $100,0.5$, and $0.1 \mu \mathrm{M}$ verbascoside concentrations. Absorbency increased when the concentration of verbascoside was decreased from 100-0.5 $\mu \mathrm{M}$ indicating that the number of alive cells increased. When the concentration of verbascoside was further decreased from 0.5-0.1 $\mu \mathrm{M}$, absorbency decreased so that the number of alive

\section{MDA-MB 231 (after 24h exposure)}
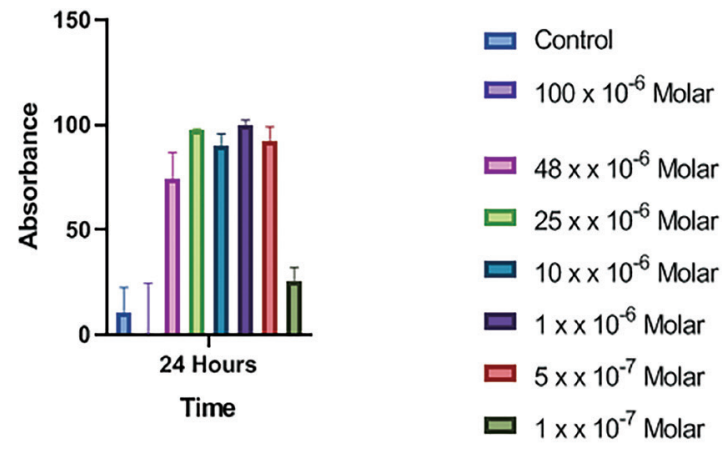

Figure 4. Two-Way ANOVA multiple comparisons test results for MDAMB231 cell line for $24 \mathrm{~h}$ exposure of verbascoside ( ${ }^{*}$ significance at $p<0.05$ ) cells decreased but the number of dead cells increased. The absorbency value at $100 \mu \mathrm{M}$ verbascoside was the lowest among the other absorbency values so that the lowest number of alive cells, but the highest number of dead cells, was at this concentration. Verbascoside of $100 \mu \mathrm{M}$ had the highest cytotoxic effect on MDA-MB $231 \mathrm{BC}$ cells after $72 \mathrm{~h}$ exposure (Figure 6).

\section{CONCLUSION AND DISCUSSION}

The prevalence of $\mathrm{BC}$ has been rising rapidly in the past decades; however, diagnosis and treatment in the early stages is very important. ${ }^{62}$ Despite advances in treatment in the early stage of $\mathrm{BC}$, many women experience recurrence and metastasis. Although treatment strategies are limited, the main focus is on medical therapy. The importance of classical treatment methods in cancer therapy is indisputable. ${ }^{63}$ Increasing cancer cases and developing resistance to drugs has urged the need for new diagnostic and treatment approaches. Since the success of traditional treatments is limited, most cancer

\section{MDA-MB 231 (after 48h exposure)}
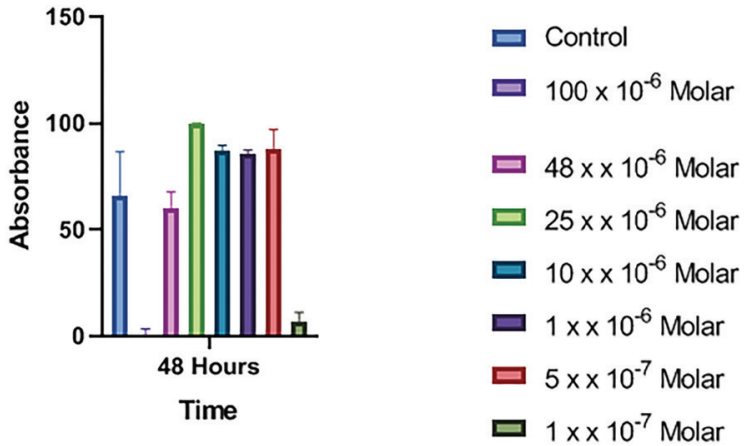

Figure 5. Two-Way ANOVA multiple comparisons test results for MDAMB231 cell line for $48 \mathrm{~h}$ exposure of verbascoside ( ${ }^{*}$ significance at $p<0.05$ )

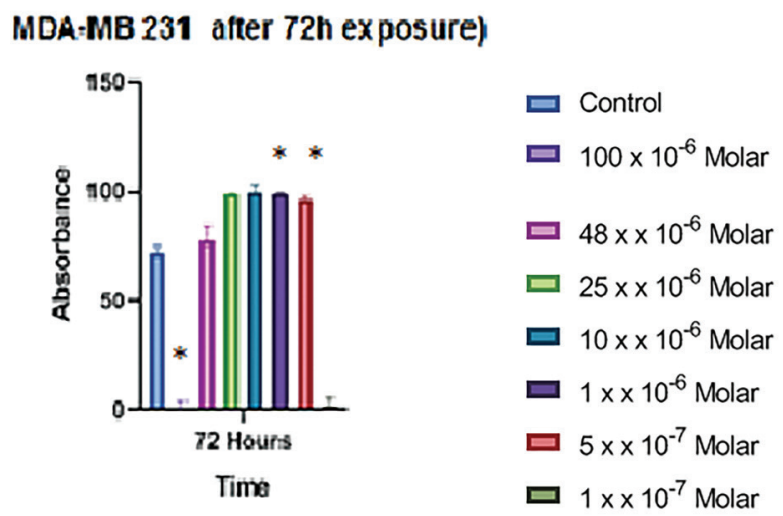

Figure 6. Two-Way ANOVA multiple comparisons test results for MDAMB231 cell line for $72 \mathrm{~h}$ exposure of verbascoside ( ${ }^{*}$ significance at $p<0.05$ ) 
patients try complementary medical therapies. There has been a growing interest in alternative treatment modalities. Finding alternative therapies with less or no side effects are essential. In recent years, alternative treatment modalities, such as natural products and anti-cancer drugs, have gained importance in BC therapy. Thus, the main aim of this study was to evaluate the cytotoxic effect of verbascoside isolated from Phlomis nissolii L. plant (Lamiaceae) in MCF-7 and MDA-MB 231 BC cell lines in vitro.

$\mathrm{IC}_{50}$ values for MCF-7 $\mathrm{BC}$ cell line after 24,48 , and $72 \mathrm{~h}$ exposure to a different concentration of verbascoside were found as $0.127,0.2174$, and $0.2828 \mu \mathrm{M}$, respectively. $R^{2}$ values for 24,48 , and $72 \mathrm{~h}$ exposure to verbascoside were calculated as $0.9630,0.8789$, and 0.8752 , respectively. Concentrations of $48,25,10,1,0.5$, and $0.1 \mu \mathrm{M}$ verbascoside were not toxic on MCF-7 BC cells after 24, 48, and $72 \mathrm{~h}$ exposure. Verbascoside of $100 \mu \mathrm{M}$ had the highest cytotoxic effect on MCF-7 BC cells only after $72 \mathrm{~h}$ exposure. In a study, verbascoside was isolated from Scrophularia subaphylla L., and researchers examined the effect of $1-1000 \mu \mathrm{g} / \mathrm{mL}$ verbascoside on MCF-7 cells and found $\mathrm{IC}_{50}$ value as $0.39( \pm 0.015) \mu \mathrm{g} / \mathrm{mL}$ after $48 \mathrm{~h}$ of exposure. ${ }^{64} \mathrm{In}$ another study, $5 \beta, 6 \beta$-dihydroxyantirrhide was isolated from Pseuderanthemum carruthersii (Seem.) Guill. var. atropurpureum (Bull.) Fosb. (Acanthaceae) leaves with13 different compounds, including verbascoside and the cytotoxic activities of these chemicals, and acetylcholinesterase inhibition against MCF-7 and HeLa cells at a concentration of $100 \mu \mathrm{g} / \mathrm{mL}$ were analyzed. Isoverbascoside and verbascoside showed fairly weak AChE inhibitory activity but showed cytotoxic activity against MCF-7 cells strongly. ${ }^{65}$ This result supports the results of our study. In another study, acteoside was isolated from the crude methanolic extract of Leucas indica flowers, and a range of concentrations of acteoside (250.00, 125.00, 62.50, 31.25, 15.63, 7.81, 3.91, 1.95, $0.98 \mu \mathrm{g} / \mathrm{mL}$ ) was tested on the MCF-7 cell line after $48 \mathrm{~h}$ of incubation. Researchers evaluated the in vitro cytotoxicity of acteoside on MCF-7 cell by using the (3-(4,5-dimethylthiazol-2yl)-2,5-diphenyltetrazolium bromide) (MTT) assay. This study tested a higher range of acteoside concentration on MCF-7 cell line than our present study, that used a range of concentrations of $100,48,25,10,1,0.5$, and $0.1 \mu \mathrm{M}$ verbascoside (acteoside) and obtained higher values of $\mathrm{IC}_{50}$ and $\mathrm{R}^{2}$ as 7.7 and 0.9968 than the current study. ${ }^{66}$ Researchers also concluded that acteoside isolated from Leucas indica flowers extract showed a significant cytotoxic activity on MCF-7 cell line, and results indicated that the antiproliferative effect strengthens with an increase in the concentration of the extract (p.2). Results of another study with verbascoside isolated from the aerial parts of Plantago lagopus $\mathrm{L}$. showed that verbascoside had strong cytotoxic activities against MCF-7 cell line, and histological analysis proved the apoptotic cell death of MCF-7 cells after the treatment of 50$100 \mu \mathrm{g} / \mathrm{mL}$ verbascoside. ${ }^{67}$ In one report, the effect of different concentrations of verbascoside isolated from $V$. ovalifolium Donn ex Sims (Scrophulariaceae) on cell viability of MCF-7 cells was measured using the MTT colorimetric assay after $48 \mathrm{~h}$ of incubation. The $\mathrm{IC}_{50}$ value for verbascoside was calculated as
$58.3 \mu \mathrm{g} / \mathrm{mL}$, and it was observed that verbascoside decreased viability by $69.6 \%$ in MCF-7 cells at $100 \mu \mathrm{g} / \mathrm{mL}$ but did not affect the viability of non-tumor MCF-10A cells (up to $100 \mu \mathrm{g} / \mathrm{mL}$ ). ${ }^{68}$ Acteoside may be effective to prevent MCF-7 BC cells because of its antiestrogenic effect. Acteoside isolated from aerial parts of Verbascum macrurum exhibited an ER-mediated significant antiestrogenic activity at a low concentration range $10^{-7}-10^{-9} \mathrm{M}$ in both the ER $\alpha$ and and ERß assay systems, indicating that acteoside may act as antagonist by itself. Acteoside at low concentration $\left(10^{-7} \mathrm{M}\right)$ demonstrated a potent inhibitory effect against estradiol $\left(10^{-9} \mathrm{M}\right)$ mainly via Ero, so that acteoside functions as antagonist for ER $\alpha$-mediated transcription. ${ }^{69}$ In contrast, in another study, 12 chemical constituents from the Callicarpa nudiflora were isolated and their cytotoxicity was evaluated by the MTT assay. The cytotoxicity assay demonstrated that the flavonoids luteoloside, lutedin-4'-0- $\beta$ D-glucoside, 6-hydroxyluteolin-7-0- $\beta$-glucoside, lutedin-7-0neohesperidoside, rhoifolin, luteolin-7, and 4'-di-O-glucoside showed monolithic proliferation inhibitory activities against Hela, A549, and MCF-7 cell lines in various concentrations. Compounds 6-hydroxyluteolin-7-0- $\beta$-glucoside and rhoifolin and iridoid glycoside nudifloside exhibited higher cytotoxicactivities. ${ }^{70}$

$I_{50}$ values for MDA-MB 231 cell line after 24,48 , and $72 \mathrm{~h}$ of exposure to different concentrations of verbascoside were found as $0.1597,0.2584$, and $0.2563 \mu \mathrm{M}$, respectively. $R^{2}$ values for 24,48 , and $72 \mathrm{~h}$ of exposure to verbascoside were calculated as $0.8438,0.5107$, and 0.9203 , respectively. Concentrations of $48,25,10,1,0.5$, and $0.1 \mu \mathrm{M}$ verbascoside are not toxic on MDAMB 231 BC cells after 24, 48, and $72 \mathrm{~h}$ exposure. Verbascoside $100 \mu \mathrm{M}$ has the highest cytotoxic effect on MDA-MB 231 BC cells after 24,48 , and $72 \mathrm{~h}$ exposure. There are few studies about the cytotoxic effects of verbascoside on MDA-MB 231 $B C$ cell line in the literature. In a study, antiproliferative effect of Strobilanthes crispus containing verbascoside on MDA-MB 231 cells was evaluated using MTT assay, and the $\mathrm{IC}_{50}$ value of methanolic extract was found as $27.2 \mu \mathrm{g} \mathrm{mL} \mathrm{m}^{-1} .71$ Another study examined the effect of dry olive mill residue water containing verbascoside and found that dry olive mill residue water inhibited MDA-MB 231 cell growth by EC value of $57.15 \pm 1.04$ c. ${ }^{72}$ Both of these studies support the idea that plant extracts containing verbascoside have cytotoxic effects on MDA-MB 231 $\mathrm{BC}$ cell line; however researchers in these studies examined the cytotoxic effects of the plant extracts containing verbascoside and any other chemicals on MDA-MB 231 cell line, unlike pure verbascoside in our study.

This study proved that verbascoside isolated from Phlomis species $L$. has cytotoxic effects on MCF-7 and MDA-MB 231 BC cells. Further studies would be performed to assess the underlying mechanisms for apoptotic induction of verbascoside extracted from Phlomis species L. In addition, detailed investigations maybe performed to evaluate the synergic effects of verbascoside isolated from Phlomis species L. with other plant extracts used in the BC treatment. 


\section{ACKNOWLEDGEMENTS}

The authors would like to thank Prof. A. Elif Erson Bensan from the Faculty of Arts and Sciences, Department of Biology, Middle East Technical University for supplying MDA-MB 231 cell lines.

Funding: This study was supported in terms of equipment and laboratories by DESAM Institute, Faculty of Medicine and Faculty of Pharmacy of Near East University, Nicosia, Yakın Doğu Bulvarı, 99138, North Cyprus, Mersin 10, Turkey.

Conflict of interest: No conflict of interest was declared by the authors. The authors are solely responsible for the content and writing of this paper.

\section{REFERENCES}

1. World Health Organization. Breast Cancer (2019). Available from: https:// www.who.int/cancer/prevention/diagnosis-screening/breast-cancer/ en/

2. TRNC Ministry of Health, Kuzey Kıbrıs Türk Cumhuriyeti'nde Kanser Kayıtçllık Projesi (2019). Available from: https://saglik.gov.ct.tr/ Portals/107/KK-Kidem\%202012 2016\%20BesYllkKanserIstatistikleri\%20 $\% 282 \% 29 . p d f$

3. Agrawal S. Late effects of cancer treatment in breast cancer survivors. South Asian J Cancer. 2014:3:112-115.

4. Mitra S, Dash R. Natural products for the management and prevention of breast cancer. Evid Based Complement Alternat Med. 2018;2018:8324696.

5. Greenwell M, Rahman PK. Medicinal plants: their use in anticancer treatment. Int J Pharm Sci Res. 2015;6:4103-4112.

6. Scarpati ML, Monache D. Isolation from Verbascum sinuatum of two new glucosides, verbascoside and isoverbascoside. Ann Chlm. 1963:53:356367

7. Birkofer L, Kaiser C, Thomas U. Acteosid und neoacteosid: Zukerester aus Syringa vulgaris. Z Naturforsch B. 1968:23:1051-1058.

8. Andary C, Wylde R, Laffite C, Privat G, Winternitz F. Structures of verbascoside and orobanchoside, caffeic acid sugar esters from Orobanche rapum-genistae. Phytochemistry. 1982:21:1123-1127.

9. Sakurai A, Kato T. A new glycoside, kusaginin isolated from Clerodendron trichotomum. Bull Chem Soc Jpn. 1983;56:1573-1574.

10. Kırmızıbekmez H, Piacente S, Pizza C, Dönmez AA, Çaliş I. Iridoid and phenylethanoid glycosides from Phlomis nissolii and P. capitata. Z. Naturforsch. 2004:59:609-613

11. Alipieva K, Korkina L, Orhan IE, Georgiev MI. Verbascoside--a review of its occurrence, (bio)synthesis and pharmacological significance. Biotechnol Adv. 2014:32:1065-1076.

12. De Marco E, Savarese M, Paduano A, Sacchi R. Characterization and fractionation of phenolic compounds extracted from olive oil mill waste waters. Food Chem. 2006;104:858-867.

13. Dell'Aquila ME, Bogliolo L, Russo R, Martino NA, Filioli Uranio M, Ariu F, Amati F, Sardanelli AM, Linsalata V, Ferruzzi MG, Cardinali A, Minervini F. Prooxidant effects of verbascoside, a bioactive compound from olive oil mill wastewater, on in vitro developmental potential of ovine prepubertal oocytes and bioenergetic/oxidative stress parameters of fresh and vitrified oocytes. Biomed Res Int. 2014;2014:878062.

14. Huber-Morath A. Phlomis. In Davis PH, eds. Flora of Turkey and the East Aegean Islands. (7th ed). Edinburgh: Edinburg University Press; 1982:102-126
15. Çalış I, Saracoğlu I, Ersöz T, Kırmızıbekmez H, Yalçın FN, Harput S. Chemotaxonomy of Turkish Phlomis L. (Lamiaceae) Genus. The Scientific and Technological Research Council of Turkey, 2004: Project Number: SBAG-2304

16. Hanoğlu A. Phytochemical Studies on the endemic phlomis species growing in Northern Cyprus. Doctorial Thesis. Kyrenia: Near East University, Graduate School of Health Sciences; 2019

17. Schönbichler SA, Bittner LK, Pallua JD, Popp M, Abel G, Bonn GK, Huck CW. Simultaneous quantification of verbenalin and verbascoside in Verbena officinalis by ATR-IR and NIR spectroscopy. J Pharm Biomed Anal. 2013:84:97-102.

18. Lee JH, Lee JY, Kang HS, Jeong $\mathrm{CH}$, Moon H, Whang WK, Kim CJ, Sim SS. The effect of acteoside on histamine release and arachidonic acid release in RBL-2H3 mast cells. Arch Pharm Res. 2006;29:508-513.

19. Li Y, Gan L, Li GQ, Deng L, Zhang X, Deng Y. Pharmacokinetics of plantamajoside and acteoside from Plantago asiatica in rats by liquid chromatography-mass spectrometry. J Pharm Biomed Anal. 2014:89:251-256

20. Mazzon E, Esposito E, Di Paola R, Riccardi L, Caminiti R, Dal Toso R, Pressi G. Cuzzocrea S. Effects of verbascoside biotechnologically produced by Syringa vulgaris plant cell cultures in a rodent model of colitis. Naunyn Schmiedebergs Arch Pharmacol. 2009;380:79-94.

21. Rao YK, Fang SH, Hsieh SC, Yeh TH, Tzeng YM. The constituents of Anisomeles indica and their anti-inflammatory activities. J Ethnopharmacol. 2009;121:292-296.

22. Lenoir L, Rossary A, Joubert-Zakeyh J, Vergnaud-Gauduchon J, Farges MC, Fraisse D, Texier O, Lamaison JL, Vasson MP, Felgines C. Lemon verbena infusion consumption attenuates oxidative stress in dextran sulfate sodium-induced colitis in the rat. Dig Dis Sci. 2011;56:3534-3545.

23. Kostyuk VA, Potapovich AI, Suhan TO, de Luca C, Korkina LG. Antioxidant and signal modulation properties of plant polyphenols in controlling vascular inflammation. Eur J Pharmacol. 2011;658:248-256.

24. Pesce M, Franceschelli S, Ferrone A, De Lutiis MA, Patruno A, Grilli A, Felaco M, Speranza L. Verbascoside down-regulates some proinflammatory signal transduction pathways by increasing the activity of tyrosine phosphatase SHP-1 in the U937 cell line. J Cell Mol Med. 2015;19:1548-1556

25. Vertuani S, Beghelli E, Scalambra E, Malisardi G, Copetti S, Dal Toso R, Baldisserotto A, Manfredini S. Activity and stability studies of verbascoside, a novel antioxidant, in dermo-cosmetic and pharmaceutical topical formulations. Molecules. 2011;16:7068-7080.

26. Caturla N, Funes L, Pérez-Fons L, Micol V. A randomized, double-blinded, placebo-controlled study of the effect of a combination of lemon verbena extract and fish oil omega-3 fatty acid on joint management. J Altern Complement Med. 2011;17:1051-1063.

27. Mestre-Alfaro A, Ferrer MD, Sureda A, Tauler P, Martínez E, Bibiloni MM, Micol V, Tur JA, Pons A. Phytoestrogens enhance antioxidant enzymes after swimming exercise and modulate sex hormone plasma levels in female swimmers. Eur J Appl Physiol. 2011;111:2281-2294.

28. Carrera-Quintanar L, Funes L, Viudes E, Tur J, Micol V, Roche E, Pons A. Antioxidant effect of lemon verbena extracts in lymphocytes of university students performing aerobic training program. Scand J Med Sci Sports. 2012;22:454-461.

29. Cardinali A, Pati S, Minervini F, D'Antuono I, Linsalata V, Lattanzio V. Verbascoside, isoverbascoside, and their derivatives recovered from olive mill wastewater as possible food antioxidants. J Agric Food Chem. 2012:60:1822-1829. 
30. Sgarbossa A, Dal Bosco M, Pressi G, Cuzzocrea S, Dal Toso R, Menegazzi M. Phenylpropanoid glycosides from plant cell cultures induce heme oxygenase 1 gene expression in a human keratinocyte cell line by affecting the balance of NRF2 and BACH1 transcription factors. Chem Biol Interact. 2012;199:87-95.

31. Alipieva K, Korkina L, Orhan IE, Georgiev MI. Verbascoside--a review of its occurrence, (bio)synthesis and pharmacological significance. Biotechnol Adv. 2014;32:1065-1076.

32. Di Giancamillo A, Rossi R, Vitari F, Carollo V, Deponti D, Corino C, Domeneghini $C$. Changes in nitrosative stress biomarkers in swine intestine following dietary intervention with verbascoside. Histol Histopathol. 2013;28:715-723.

33. Sheng GQ, Zhang JR, Pu XP, Ma J, Li CL. Protective effect of verbascoside on 1-methyl-4-phenylpyridinium ion-induced neurotoxicity in PC12 cells. Eur J Pharmacol. 2002;451:119-124.

34. Pu X, Song Z, Li Y, Tu P, Li H. Acteoside from Cistanche salsa inhibits apoptosis by 1-methyl-4-phenylpyridinium ion in cerebellar granule neurons. Planta Med. 2003;69:65-66.

35. Backhouse N, Delporte C, Apablaza C, Farías M, Goïty L, Arrau S, Negrete $\mathrm{R}$, Castro C, Miranda H. Antinociceptive activity of Buddleja globosa (matico) in several models of pain. J Ethnopharmacol. 2008;119:160-165.

36. Deng M, Ju X, Fan D, Tu P, Zhang J, Shen Y. Verbascoside rescues the SHSY5Y neuronal cells from MPP+ induced apoptosis. Chin Pharmacol Bull. 2008;24:1297-1302.

37. Wang H, Xu Y, Yan J, Zhao X, Sun X, Zhang Y, Guo J, Zhu C. Acteoside protects human neuroblastoma $\mathrm{SH}-\mathrm{SY} 5 \mathrm{Y}$ cells against beta-amyloidinduced cell injury. Brain Res. 2009;1283:139-147.

38. Esposito E, Mazzon E, Paterniti I, DalToso R, Pressi G, Caminiti R, Cuzzocrea. PPAR- $\alpha$ contributes to the anti-inflammatory activity of verbascoside in a model of inflammatory bowel disease in mice. PPAR Res. 2010;2010:917312.

39. Kahraman C, Tatli II, Orhan IE, Akdemir ZS. Cholinesterase inhibitory and antioxidant properties of Verbascum mucronatum Lam. and its secondary metabolites. Z Naturforsch C J Biosci. 2010;65:667-674.

40. Filho AG, Morel AF, Adolpho L, Ilha V, Giralt E, Tarragó T, Dalcol II. Inhibitory effect of verbascoside isolated from Buddleja brasiliensis Jacq. ex Spreng on prolyl oligopeptidase activity. Phytother Res. 2012;26:1472-1475.

41. Lin J, Gao L, Huo SX, Peng XM, Wu PP, Cai LM, Yan M. [Effect of acteoside on learning and memory impairment induced by scopolamine in mice]. Zhongguo Zhong Yao Za Zhi. 2012;37:2956-2959.

42. Wang $H Q, X u Y X, Z h u C Q$. Upregulation of heme oxygenase-1 by acteoside through ERK and PI3 K/Akt pathway confer neuroprotection against beta-amyloid-induced neurotoxicity. Neurotox Res. 2012;21:368378.

43. Kurisu M, Miyamae Y, Murakami K, Han J, Isoda H, Irie K, Shigemori $\mathrm{H}$. Inhibition of amyloid $\beta$ aggregation by acteoside, a phenylethanoid glycoside. Biosci Biotechnol Biochem. 2013;77:1329-1332.

44. Azimi H, Fallah-Tafti M, Khakshur AA, Abdollahi M. A review of phytotherapy of acne vulgaris: perspective of new pharmacological treatments. Fitoterapia. 2012;83:1306-1317.

45. Funari CS, Gullo FP, Napolitano A, Carneiro RL, Mendes-Giannini MJ, Fusco-Almeida AM, Piacente S, Pizza C, Silva DH. Chemical and antifungal investigations of six Lippia species (Verbenaceae) from Brazil. Food Chem. 2012;135:2086-2094.
46. Maquiaveli CDC, Rochetti AL, Fukumasu H, Vieira PC, da Silva ER. Antileishmanial activity of verbascoside: Selective arginase inhibition of intracellular amastigotes of Leishmania (Leishmania) amazonensis with resistance induced by LPS plus IFN- $\gamma$. Biochem Pharmacol. 2017;127:2833.

47. Korkina L, Pastore S. The role of redox regulation in the normal physiology and inflammatory diseases of skin. Front Biosci (Elite Ed). 2009;1:123-141.

48. Pastore S, Lulli D, Fidanza P, Potapovich Al, Kostyuk VA, De Luca C, Mikhal'chik E, Korkina LG. Plant polyphenols regulate chemokine expression and tissue repair in human keratinocytes through interaction with cytoplasmic and nuclear components of epidermal growth factor receptor system. Antioxid Redox Signal. 2012;16:314-328.

49. Kostyuk VA, Potapovich Al, Lulli D, Stancato A, De Luca C, Pastore S, Korkina L. Modulation of human keratinocyte responses to solar UV by plant polyphenols as a basis for chemoprevention of non-melanoma skin cancers. Curr Med Chem. 2013;20:869-879.

50. Muñoz E, Avila JG, Alarcón J, Kubo I, Werner E, Céspedes CL. Tyrosinase inhibitors from Calceolaria integrifolia s.l.: calceolaria talcana aerial parts. J Agric Food Chem. 2013;61:4336-4343.

51. Potapovich Al, Kostyuk VA, Kostyuk TV, de Luca C, Korkina LG. Effects of pre- and post-treatment with plant polyphenols on human keratinocyte responses to solar UV. Inflamm Res. 2013;62:773-780.

52. Korkina LG. Phenylpropanoids as naturally occurring antioxidants: from plant defense to human health. Cell Mol Biol (Noisy-le-grand). 2007;53:15-25.

53. Wartenberg M, Budde $P$, De Mareés $M$, Grünheck $F$, Tsang SY, Huang $Y$, Chen ZY, Hescheler J, Sauer H. Inhibition of tumor-induced angiogenesis and matrix-metalloproteinase expression in confrontation cultures of embryoid bodies and tumor spheroids by plant ingredients used in traditional chinese medicine. Lab Invest. 2003;83:87-98.

54. Zhang F, Jia Z, Deng Z, Wei Y, Zheng R, Yu L. In vitro modulation of telomerase activity, telomere length and cell cycle in MKN45 cells by verbascoside. Planta Med. 2002;68:115-118.

55. Lee KW, Kim HJ, Lee YS, Park HJ, Choi JW, Ha J, Lee KT. Acteoside inhibits human promyelocytic HL-60 leukemia cell proliferation via inducing cell cycle arrest at G0/G1 phase and differentiation into monocyte. Carcinogenesis. 2007;28:1928-1936.

56. Chen M, Bin Huang YZ, Yang X, Wu Y, Liu B, Yuan Y, Zhang G. Evaluation of the antitumor activity by ni nanoparticles with verbascoside. J Nanomater. 2013;2013:62349.

57. Zhang F, Jia Z, Deng Z, Wei Y, Zheng R, Yu L. In vitro modulation of telomerase activity, telomere length and cell cycle in MKN45 cells by verbascoside. Planta Med. 2002;68:115-118.

58. Zhou L, Feng Y, Jin Y, Liu X, Sui H, Chai N, Chen X, Liu N, Ji Q, Wang Y, Li $Q$. Verbascoside promotes apoptosis by regulating HIPK2-p53 signaling in human colorectal cancer. BMC Cancer. 2014;14:747.

59. Zhang Y, Yuan Y, Wu H, Xie Z, Wu Y, Song X, Wang J, Shu W, Xu J, Liu B, Wan L, Yan Y, Ding X, Shi X, Pan Y, Li X, Yang J, Zhao X, Wang L. Effect of verbascoside on apoptosis and metastasis in human oral squamous cell carcinoma. Int J Cancer. 2018;143:980-991.

60. Jia WQ, Wang ZT, Zou MM, Lin JH, Li YH, Zhang L, Xu RX. Verbascoside inhibits glioblastoma cell proliferation, migration and Invasion while promoting apoptosis through upregulation of protein tyrosine phosphatase shp-1 and inhibition of stat3 phosphorylation. Cell Physiol Biochem. 2018;47:1871-1882. 
61. Wartenberg M, Budde P, De Mareés M, Grünheck F, Tsang SY, Huang Y, Chen ZY, Hescheler J, Sauer H. Inhibition of tumor-induced angiogenesis and matrix-metalloproteinase expression in confrontation cultures of embryoid bodies and tumor spheroids by plant ingredients used in traditional chinese medicine. Lab Invest. 2003;83:87-98.

62. Parkin DM, Bray F, Ferlay J, Pisani P. Global cancer statistics, 2002. CA Cancer J Clin. 2005;55:74-108.

63. Aggarwal BB, Shishodia S. Molecular targets of dietary agents for prevention and therapy of cancer. Biochem Pharmacol. 2006;71:13971421.

64. Delazar A, Asnaashari S, Nikkhah E, Asgharian P. Phytochemical analysis and antiproliferative activity of the aerial parts of Scrophularia subaphylla. Res Pharm Sci. 2019;14:263-272.

65. Nga VT. Constituents of the leaves of Pseuderanthemum carruthersii (Seem.) Guill. var. atropurpureum (Bull.) Fosb. Amsterdam, Netherlands: Elsevier; 2017.

66. Vinayagam A, Sudha PN. In Vitro cytotoxicity activity of acteoside from leucas Indica flowers. Indian J Appl Resç 2014:4:1-3.

67. Harput US, Genc Y, Saracoglu I. Cytotoxic and antioxidative activities of Plantago lagopus $L$. and characterization of its bioactive compounds. Food Chem Toxicol. 2012;50:1554-1559.
68. Vasincu A, Neophytou CM, Luca SV, Skalicka-Woźniak K, Miron A, Constantinou Al. 6-0-(3", 4"-di-O-trans-cinnamoyl)- $\alpha-l-$ rhamnopyranosylcatalpol and verbascoside: Cytotoxicity, cell cycle kinetics, apoptosis, and ROS production evaluation in tumor cells. J Biochem Mol Toxicol. 2020;34:e22443.

69. Papoutsi Z, Kassi E, Mitakou S, Aligiannis N, Tsiapara A, Chrousos GP, Moutsatsou P. Acteoside and martynoside exhibit estrogenic/ antiestrogenic properties. J Steroid Biochem Mol Biol. 2006;98:63-71.

70. Ma YC, Zhang M, Xu WT, Feng SX, Lei M, Yi B. [Chemical constituents from Callicarpa nudiflora and their cytotoxic activities]. Zhongguo Zhong Yao Za Zhi. 2014;39:3094-3101.

71. Rahmat A, Edrini S, Akim A, Ismail P, Hin TYY, Abu Bakar MF. Anticarcinogenic properties of strobilanthes crispus extracts and its compounds in vitro. Int J Cancer Res. 2006:2:47-49.

72. Ramos P, Santos SAO, Guerra AR, Guerreiro O, Felício L, Jerónimo $E$, Silvestre AJD, Neto CP, Duarte M. Valorization of olive mill residues: Antioxidant and breast cancer antiproliferative activities of hydroxytyrosol-rich extracts derived from olive oil by-products, Ind Crops and Prod. 2013;46:359-368. 